\title{
CAD/CAM SYSTEMS IN EDUCATION IN SECONDARY ENGINEERING SCHOOLS
}

\section{Vladimír SOTÁK - Martin KUNÍK - Robert SOTÁK}

\begin{abstract}
Development of technologies used to ensure production processes, especially in engineering production requires a change in the system of teaching at secondary vocational schools and universities. Computer skills have become an essential literacy of the contemporary society and the rapid development of software to support production requires careful and detailed preparation of students in order to withstand the competitive environment of the labour market. This contribution presents the authors' own experiences and illustrates the current state in methodological provision of education in those subjects that were added into the curricula based on the demands of practice. They present results of the research which takes part in the dissertation topic dealing with teaching CADCAM systems. Based on the findings they analyze the current situation in teaching CAD-CAM systems at secondary schools and universities. One of the crucial conclusions shows the lack of relevant study material. According to the recommendation for practice, it is necessary to begin to approach this issue much more responsibly and systematically.
\end{abstract}

Key words: CAD, CAM, manufacturing processes, computer skills, software support, programming, educational standards, teaching process.

\section{SYSTÉMY CAD/CAM VO VYUČOVANÍ NA SPŠ STROJÁRSKYCH}

Resumé: Vývoj technológií pre zabezpečenie výrobných procesov najmä v strojárskej výrobe vyžaduje zmenu v systéme vyučovania na stredných odborných a vysokých školách. Do popredia sa dostávajú najmä počítačové zručnosti a rýchly vývoj programového vybavenia pre podporu výroby vyžaduje precíznu prípravu študentov tak, aby obstáli v náročnom prostredí trhu práce. Predkladaný príspevok prezentuje vlastné skúsenosti autorov a mapuje súčasný stav v metodickom zabezpečení výučby tých predmetov, ktoré boli zaradené do vyučovacích osnov na základe požiadaviek praxe. Prezentujú výsledky výskumu, ktorý je súčast’ou dizertačnej práce s tématikou výučby CAD-CAM systémov. Na základe zistených skutočností analyzujú súčasnú situáciu vo vyučovaní CAD-CAM systémov na stredných a vysokých školách. Konštatujú najmä nedostatok relevantného študijného materiálu. Dospeli kzáveru, že je potrebné začat' pristupovat' $\mathrm{k}$ tejto téme zodpovednejšie a systematicky.

Kl'účové slová: CAD, CAM, výrobné procesy, počítačové zručnosti, softvérová podpora, programovanie, vzdelávací štandard, vyučovací proces.

\section{Introduction}

CAD and CAM systems have become an essential part of manufacturing process in engineering companies that want to fight and withstand in competitive market environment. PC supported production is the fundamental condition for obtaining a commission. The leader is so-called auto incentive. Concerns that want to join and obtain commissions from the area of automotive production must prove their ability to provide the first-rate level quality of subdeliveries. Using of computer technologies and software support has obviously increased the efficiency of all production processes, from the moment of creation (design) up to the manufacturing of particular components. They also indisputably take part in the construction, assembling of components into subconfigurations, configurations and finally into the machines themselves. Based on the abovementioned, there is a tendency to implement IT into the educational process at all secondary engineering schools. Recently, teaching CAM and CAD systems has been implemented into the education plan of the Ministry of Education in the form of optional subjects and by this authority CAD/CAM Systems, Graphic Systems, Programming of CNC Machines have been recommended for the teaching practice. 
2 The Issue of Implementation of the Systems into the Education

According to our findings, the CAD/CAM systems are taught in many different subjects at our secondary schools. There were some obstacles in implication of teaching $\mathrm{CAD} / \mathrm{CAM}$ systems into the educational practice, some of the crucial questions were:

- What software would be the most suitable?

- Who would teach the CAD/CAM systems?

- How to teach the CAD/CAM systems?

- How to incorporate the CAD/CAM systems into the educational process?

The situation in implication $\mathrm{CAD} / \mathrm{CAM}$ systems into the educational process has been influenced by these deficiencies

- no methodology of teaching CAD/CAM systems

- no educational standard

- no publications, secondary school textbooks for teaching $\mathrm{CAD} / \mathrm{CAM}$ systems

- the lack of qualified teachers

- non-existing system of education of pedagogical workers with orientation on $\mathrm{CAD} / \mathrm{CAM}$ systems

Notwithstanding the importance of $\mathrm{CAD} / \mathrm{CAM}$ systems for the engineers, responsible authorities do absolutely nothing for the increasing of teaching quality of the abovementioned systems. Long awaited reform of the School Act has not been able do deal with the problem. Status of $\mathrm{CAD} / \mathrm{CAM}$ system has remained in the very same position (still they are optional). Schools are responsible for - the subjects they teach

- how many lessons per week they offer

Although headmasters have a competence to change the structure of optional subjects, still they do not fully use it and continue in teaching particular fields only with minimal changes. They do not try to gain the maximum from the positive effect of the new School Act for improving the teaching process; vice versa, they still criticize its negatives.

It probably might be useful, if the Board of Directors would be able to agree on a ,common advance plan" and started construction dialogue with the Ministry aimed to eliminate prevailing deficiencies. In the process of negotiations they may use the support of ,practice demands" for the qualification demands on the workers. I tis generally wide-spread abroad that employers cooperate on the creation of educational programmes with the aim to secure constant supply of qualified work force.

Here, in the Slovak Republic, we are fully aware of the qualification demands of practice in the area of computer literacy. Nowadays, a good engineer can not operate without appropriate knowledge of CAD/CAM systems. That is why we should elaborate a new educational conception in the area of CAD/CAM systems compatible with the contemporary demands of the market.

We have recently worked out a new conception proposal for CAD/CAM systems. Our goal was to create an educational standard for this field and the AutoCad had been selected as a platform for the new standard. This system is widely used in the engineering practice as well as a teaching aid at schools. Because of some difficulties in assembling the methodology and extreme time-consumption of the experimental testing of particular methods, we have decided to deal only with the 2D CAD systems.

We have set some partial aims of our work to obtain relevant information:

- obtaining information on the most widespread $\mathrm{CAD} / \mathrm{CAM}$ systems in engineering practice

- obtaining information about the most used $\mathrm{CAD} / \mathrm{CAM}$ systems at secondary engineering schools

- obtaining information on the qualification of pedagogues teaching CAD/CAM systems

- comparison of the widely used CAD and CAM systems, evaluation and choice of the most suitable $\mathrm{CAD} / \mathrm{CAM}$ systems for teaching at secondary engineering schools

- elaboration of methodology for teaching selected 2D CAD system

- elaboration of educational standard for teaching CAD systems

and then we constructed following hypotheses:

H0: Teaching of CAD systems through proposed methodology will be more efficient in the experimental group than in the control group being taught traditionally

Changes in cognitive area have been chosen as fundamental criteria of teaching efficiency. We shall compare outcomes of experimental and control groups through the final didactic test. Questions in the test are mainly orientated on memorizing of knowledge, comprehension, specific transfer and the long term knowledge preservation. 
H1: Students from the experimental group being taught via new methodology shall obtain higher cognitive level in CAD system in the final test than students from the control group

$\mathrm{H} 2$ : Students from the experimental group being taught via new methodology shall obtain higher score in the final test in the area of the long term knowledge preservation than students from the control group.

Chart1. Survey of used methods
H3: Students from the experimental group being taught via new methodology shall obtain higher score in the final test in the area of specific transfer of the CAD systems knowledge than students from the control group.

In the following chart we show the survey of methods used to prove particular hypotheses

\begin{tabular}{|l|l|}
\hline Hypotheses & Methods \\
\hline Hypothesis H0 & Experiment, didactic test \\
\hline Hypothesis H1 & Didactic test \\
\hline Hypothesis H2 & Didactic test \\
\hline Hypothesis H3 & Didactic test \\
\hline
\end{tabular}

Based on their personal experience, teachers who have been dealing with CAD systems for some years created own methodical approaches in teaching CAD systems that has been tested in the practical teaching unit and seem to be optimal. Comparing those methods we have found out that all of them meet in some common points. We subsequently used these common points for elaboration of our methodology that was put to the test at the Technical Drawing lesson due to connection between CAD system and the above-mentioned subject. By evaluation of the tests we found out that some students have a problem with space discrimination and many of them do not pay full attention when reading task information. To verify the methodology among teachers themselves, we decided to use the method of controlled dialogue. Questionnaire outcomes has resulted into the following:

- not a single teacher is satisfied with the set of methodical instructions for teaching CAD/CAM systems that have been created at a superficial level. It means, the only recommendation of the Ministry of Education was the statement that the $\mathrm{CAD} / \mathrm{CAM}$ systems should be taught at schools. In facts, this can not be considered a methodical instruction!

- Teachers miss the teaching standard

- Teachers criticized the lack of suitable textbooks written in Slovak language. Unfortunately, they still use Czech textbooks that are definitely not suitable as a study material in the educational process. From the teachers' point of view they are considered more handbooks than textbooks and only coincidently they were called textbooks for AutoCAD 20xx, what they truly are not!

- Teachers are not satisfied with high hardware demands of the latest system versions; they have got some troubles to start them even on the brand new computers.

\section{Conclusion}

According to the personal experience and thanks to the discussions with teachers we confirmed the fact that the recipe how to teach $\mathrm{CAD} / \mathrm{CAM}$ systems lies in an urgent and radical solution. It is needed to elaborate the system of education not only of students, but even of teachers. Provision of adequate textbooks regarding all pedagogical and methodical aspects of educational process for $\mathrm{CAD} / \mathrm{CAM}$ systems is a must. We should change all the so-called CAD textbooks for really valuable textbooks that can be used even in self-preparation of students. This complete process starts in elaboration and implication of high quality methodical instructions and educational standard for teaching $\mathrm{CAD} / \mathrm{CAM}$ systems. At the same time, the Ministry of Education should put in a claim for the CAD software producers to create such programs whose hardware demands would be acceptable under condition of retaining the expected quality. This might help widen the accessibility of the CAD/CAM system even for less solvent clients.

\section{Bibliography}

[1] BUŠ, L.: Školní software a komerční projekty? In: IT CAD, roč. 14, 2004, č. 6 , s. $42-43$. 
[2] DVOŘÁK, D. : Efektivní učení ve škole. Praha : Portál, 2005. 144s. ISBN 80-7178-556-3. [3] FABIAN, M.: Požiadavky strojárskej praxe. CA.. gramotnost', jedna zo základných požiadaviek strojárskej praxe. In: IT CAD, roč. 12, 2002, č.6, s. 32-34.

[4] GAVORA, P. : Výzkumné metody v pedagogice. Brno : Paido, 1995. 130s. ISBN 80-85931-15-X.

[5] Jakubová - Galan - Morong: Zavedenie grafických systémov do vyučovacieho procesu stredných odborných škôl [online], Bratislava: ŠIOV, 1999. 2002 [2007-08-05]. Dostupné na internete:

http://www.siov.sk/siov/dokhtm/1vzdprog/64zav grs.htm

[6] MALÝ, J.: CAD/CAM systémy ve školství. In: IT CAD, roč. 9, 1999, č. 2, s. 28-29.

[7] PETLÁK, E. : Všeobecná didaktika. Bratislava : Iris, 1997. 270s.

ISBN 80-88778-49-2.
[8] PETLÁK, E. : Všeobecná pedagogika. Bratislava : Iris, 1997. 331s.

ISBN 80-89018-64-5.

[9] Průcha, J. : Pedagogický výzkum. Uvedení do teorie a praxe. Praha : Karolinum, 1995. 132s. ISBN 80-7184-132-3.

Doc. Ing. Vladimír Soták, CSc.

Mgr. Martin Kuník

PaedDr.. Robert Soták

Katedra techniky a informačných technológií

PF UKF v Nitre

Dražovská cesta 4 Nitra

E-mail: vsotak@ukf.sk,

martin.kunik@azet.sk, robert.sotak@ukf.sk 